\title{
PRODUCTIVITY AND QUALITY OF AUTUMN SUGAR CANE RATOON INTERCROPPED BY WHEAT OR BARLEY UNDER MIDDLE EGYPT CONDITIONS
}

\author{
(Received: 8. 10. 2012)
}

\author{
By \\ N. R. Ahmed, Kh. El-Sh. Mohamed* and H. Ferweez* \\ Field Crops Research Institute \& *Sugar Crops Research Institute, \\ Agriculture Research Center, Giza, Egypt.
}

\begin{abstract}
Sometimes under Middle Egypt conditions, intercropping wheat with sugar cane could be delayed due to the delay of cutting the cane but intercropping barley with sugar cane in this case would be appropriate. Therefore, four field experiments were conducted at Mallawi Agric. Res. Station, El- Minia - Egypt (intercropping wheat or barley on cane, third ratoon) during the two seasons 2009/2011 and 2010/2012 to study the effect of intercropping one, two and three rows of wheat or barley on the productivity, quality and profitability of sugar cane in a complete randomized blocks design.

The obtained results could be summarized as follows: Intercropped yield of sugar cane with one, two and three rows of wheat was $99.94,99.24$ and $98.39 \%$ in the $1^{\text {st }}$ season, $99.80,82.37$ and $80.92 \%$ in the $2^{\text {nd }}$ season compared with sugar cane alone, respectively. The intercropped yield of sugar cane with one, two and three rows of barley was $98.31,97.00$ and $94.93 \%$ in the $1^{\text {st }}$ season , 98.03, 95.86 and $92.31 \%$ in the $2^{\text {nd }}$ season compared with pure stand of sugar cane, respectively.

The intercropping patterns of wheat or barley with sugar cane had a significant effect on sugar recovery $\%$ of intercropped sugar cane with wheat and purity\% of intercropped sugar cane with barley in the $1^{\text {st }}$ season.

The highest values of land equivalent ratio LER are 1.33 and 1.50 obtained by intercropping three rows of wheat or barley with sugar cane in the $1^{\text {st }}$ and the $2^{\text {nd }}$ seasons, respectively. Aggressivity (Agg) values of autumn sugar cane were negative (dominated) while those of wheat or barley were positive (dominant) by intercropping one, two or three rows of wheat or barley with sugar cane in the $1^{\text {st }}$ and the $2^{\text {nd }}$ seasons, except intercropping three rows of wheat with sugar cane in the $2^{\text {nd }}$ season.

The economic return of output of intercropping wheat or barley on sugar cane was profitable for growers compared to the single cane, as well as an increase for cultivated area and productivity of wheat crop, which represents one of the strategic crops of El-Minia Governorate.

From these results, it could be concluded that intercropping cane with wheat and intercropping cane with barley if sugar cane was cut early and if sugar cane was delayed, respectively under the Middle Egypt conditions.
\end{abstract}

Key words: barley - intercropping - LER - Pol\% - sugar cane-TSS\% - wheat yield (ton/fed).

\section{INTRODUCTION}

Intercropping is considered one of the important means of solving or reducing the large gap between the production and consumption of different crops such as cereals. Autumn sugar cane ratoon occupies the land for more than one year and hence the farmers have no chance to grow another crop. During winter season and early spring, sugar cane grows slowly due to the prevailing low temperature. Therefore, attention was focused on some annual winter crops with short duration. Wheat (Triticum aestivum, L.) is the most important cereal grown in the world and is a staple food of the people in Egypt. Some sugar cane growers in El-Minia Governorate, after early cutting of sugar cane, in such case, intercropping wheat with sugar cane in the last week of Nov the ember or the first week of December would help growers getting additional income during the growing season of sugar cane. But, the late cutting of sugar cane in the last week of December or first week of January is not suitable for intercropping wheat with sugar cane. (CCSC, 2012). El.Gergawi et al. (1995) and Eweida et al. (1996) reported that yields of sugar cane and other intercropped crops were 
significantly reduced under intercropping conditions compared with pure stand of sugar cane. They mentioned that intercropping wheat with sugar cane increased land usage, LER (Land Equivalent Ratio ) and relative crowding coefficient. Zohry (1997) showed that sugar cane yield ton/fed slightly decreased by intercropping, the highest reduction values of cane yield were 9.9 and $8.4 \%$ in the two seasons, respectively when intercropped with 5 rows of onion. He added that, most sugar cane quality parameters (Brix, sucrose and purity percentages) were unaffected by intercropping. Hussein et al. (2000) pointed out that the maximum value of sugar cane tillers /stump was scored in sole sugar cane, while , intercropping gave the lowest value. Some investigators such as Nazir, et al. (2002) found that sucrose $\%$ of cane juice was not significantly affected by different intercrops ( sarsoon, sunflower, wheat, gram, lentil, peas and garlic). Farghaly (2003) demonstrated that planting one row of sugar beet at a distance of $30 \mathrm{~cm}$ between hills on cane ridges was successful and profitable compared with 20 and $25 \mathrm{~cm}$ hill spacing. Zohry and Abd El.Aal (2003) showed that intercropping three rows of mung bean with sugar cane is successful and profitable, which reduced the cost of weed control and in some instances increased sugar yield (ton/fed). Huger, (2006) studied the intercropping cowpea, French bean and coriander) with maize and found that overall performance of the cropping system was largely enhanced when maize and vegetables were intercropped compared to their sole performance.

The present investigation was carried out to define precisely the competition effect of intercropping wheat or barley on productivity, quality and profitability of sugar cane under Middle Egypt conditions.

\section{MATERIALS AND METHODS}

Four field experiments were conducted at Mallawi Agric. Res. Station, Minia Governorate, Egypt, during 2009/2011 and 2010/2012 seasons to study the effect of intercropping wheat or barley on the productivity, quality and profitability of sugar cane (Third ratoon). Sugar cane variety namely G.T.54-9 (the commercial variety) was used.

A randomized complete blocks design (RCBD) with four replicates was applied including five treatments as follows:

1-Sugar cane + one row of wheat or barley $(15 \%$ of sole wheat or barley).

2 -Sugar cane + two rows of wheat or barley $(30 \%$ of sole wheat or barley).

3-Sugar cane + three rows of wheat or barley (45\% of sole wheat or barley).

4- Sole stand of wheat or barley.

5- Sole stand of sugar cane.

Sowing and cutting, or harvesting dates of sugar cane, wheat and barley crops are recorded in Table (A).

Plot area was $25 \mathrm{~m}^{2}$; it consisted of 5 ridges, 5 $\mathrm{m}$ length $\mathrm{x} 1 \mathrm{~m}$ width. Sugar cane was planted in ridges, one meter apart, while wheat or barley was planted in hills, $15 \mathrm{~cm}$ apart. Distances between rows of wheat or barley were $15 \mathrm{~cm}$ where intercropping with two and three rows of wheat or barley. Phosphorus fertilizer was added in the form of calcium super-phosphate $\left(15.5 \% \mathrm{P}_{2} \mathrm{O}_{5}\right)$ at the rate of $60 \mathrm{~kg} / \mathrm{fed}$, which was broadcasted after ridging in furrows after sowing wheat or barley and before irrigation. Recommended fertilization of $60 \mathrm{~kg} \mathrm{~N} / \mathrm{fed}$ as Urea (46\%) was applied in three equal doses before each of the first, second and third irrigations. Potassium fertilizer was added as potassium sulphate $\left(48 \% \mathrm{~K}_{2} \mathrm{O}\right)$ at the rate of $48 \mathrm{~kg}$ $\mathrm{K}_{2} \mathrm{O} /$ fed after full emergence for the third ratoon after harvesting wheat or barley. Nitrogen fertilizer was added as Urea $(46 \%)$ at the rate of $210 \mathrm{~kg} / \mathrm{fed}$ in two equal doses as side dressing in cane rows, the first one after harvesting wheat or barley and one month later. All the required agricultural practices were done as followed by sugar cane growers in the region. Some chemical and physical properties of the soil of the experimental site were determined before seed bed

Table (A): Sowing and cutting or harvesting dates of sugar cane, wheat and barlely crops during 2009 / 2011 and 2010 / 2012 seasons.

\begin{tabular}{|l|l|l|l|}
\hline Crops & Sowing dates & Grown cultivar & Cutting or harvesting dates \\
\hline \multicolumn{5}{|c|}{$2009 / 2011$ season } \\
\hline Sugar cane & $3 / 12 / 2009$ & G.T. 54-9 & $18 / 1 / 2011$ \\
\hline Wheat & $7 / 12 / 2009$ & Beni Suef & $28 / 4 / 2010$ \\
\hline Barley & $2 / 1 / 2010$ & G.129 & $18 / 4 / 2010$ \\
\hline \multicolumn{5}{|c|}{$2010 / 2012$ season } \\
\hline Sugar cane & $2 / 12 / 2010$ & G.T. 54-9 & $13 / 1 / 2012$ \\
\hline Wheat & $5 / 12 / 2010$ & Beni Suef & $26 / 4 / 2011$ \\
\hline Barley & $3 / 1 / 2011$ & G.129 & $22 / 4 / 2011$ \\
\hline
\end{tabular}


preparation according to the procedures outlined by Jackson (1967). The physical analysis of the experimental site showed that the soil was silty clay loam. Its chemical analysis cleared that the soil contained 21.1 and $19.35 \mathrm{ppm} \mathrm{N}, 8.50$ and $7.85 \mathrm{ppm} \mathrm{P}, 175$ and $180 \mathrm{ppm} \mathrm{K}$ with pH of 8.10 and 8.00 in the $1^{\text {st }}$ and the $2^{\text {nd }}$ seasons, respectively.

\subsection{The recorded data}

2.1.1.For sugar cane: At harvest time 20 guarded plants of sugar cane were harvested at the age of 13 months were taken from each plot to estimate the following traits:

- Stalk height $(\mathrm{cm})$ : It was measured from soil surface to the top visible dewlap.

- Stalk diameter $(\mathrm{cm})$ : It was measured at the middle part of the stalk.

- Stalk weight (kg.).Number of stalks $/ \mathrm{m}^{2}$ was counted.

- Total soluble solid percentage (TSS \%), which was determined using "Brix hydrometer" standardized at $20 \mathrm{C}^{0}$ as shown by A.O.A.C. (2005).

- Sucrose \%, was determined using "Sacharemeter" accoding to A.O.A.C. (2005).

- Juice purity \%, was estimated according to Satisha et al. (1996) using the following equation:Purity $\%=$ sucrose $\%$ x $100 /$ TSS $\%$. .

- Pol \% of cane stalks, which was calculated using the following equation, after the determination of sucrose \% in the cane juice, according to Satisha et al. (1996).

Pol \% = $\left[\right.$ Brix \% $-(\text { Brix \% - sucrose \%) } 0.4]^{*}$ 0.73 .

- Sugar recovery \% (rendment) was calculated using the following equation, according to the procedures used by the Sugar and Integrated Industries Co.

Sugar recovery $=[($ pol- 0.8$) /$ Purity $] *($ Purity $\%-$ 40)/100-60.

- Reducing sugars of cane juice was determined according to A.O.A.C. (2005). Millable cane yield (ton/fed): cane stalks of the guarded rows were harvested at age of 12 months, topped, cleaned, weighed and cane yield was calculated as ton/fed.

- Recoverable sugar yield (ton/fed), was estimated according to the following equation reported by Mathur (1981):

Recoverable sugar yield $($ ton/fed $)=$ millable cane yield (ton/fed) x Sugar recovery $\%$.

2.1.2.For wheat and barley: At harvest time 20 guarded plants were taken randomly from each plot to estimate plant height $\left(\mathrm{cm}_{-}\right)$, spike length $(\mathrm{cm})$, weight of grains/ spike $(\mathrm{g})$, weight of 100 grains (g), number of grains/ spike , grain yield (ardab /fed)and straw yield (ton/fed) .

2.1.3. Light intensity: The light transmission by the canopies of sole sugar cane, sole intercrops (wheat and barley) and intercropping system was measured by Lux meter. The light intensity above canopy $\left(\mathrm{I}_{0}\right)$ and the ground level (I) was recorded between 12:30 and 1:00 pm and light transmission ratio (LTR) was averaged for the system based on row proportions. $\mathrm{LTR}=\mathrm{I} / \mathrm{I}_{0} \mathrm{X} 100$, where, $\mathrm{I}=$ Light intensity received at the ground level and $\mathrm{I}_{0}$ $=$ light intensity received at the top of crop canopy by TES 1330 Digital according to Mendoza (1986).

\subsubsection{Competitive relationships and yield advantage}

1.Land Equivalent Ratio (LER ) according to Willey (1979) using the following formula :

$$
\mathrm{LER}=\frac{\mathrm{yab}}{\mathrm{yaa}}+\frac{\mathrm{yba}}{\mathrm{ybb}}
$$

Where: yaa $=$ pure stand yield of species a $y b b=$ pure stand yield of species $b$ $y a b=$ mixture yield of a (when combined with b )

$y b a=$ mixture yield of $b($ when combined with a )

2.Relative crowding coefficient K (RCC) according to Hall (1974).

$$
\mathrm{K}=\mathrm{k}_{\mathrm{ab}} \times \mathrm{kba}
$$

Where: $k_{a b}=\left(Y_{a b} \times z_{b a} \%\right) /\left(Y_{a a}-Y_{a b}\right) \times z_{a b} \%$

$\mathrm{k}_{\mathrm{ba}}=\left(\mathrm{Y}_{\mathrm{ba}} \times \mathrm{z}_{\mathrm{ab}} \%\right) /\left(\mathrm{Y}_{\mathrm{bb}}-\mathrm{Y}_{\mathrm{ba}}\right) \mathrm{x}_{\mathrm{ba}} \%$

$\mathrm{Z}_{\mathrm{ba}} \%=$ Area occupied by sugar cane

$\mathrm{Z}_{\mathrm{ab}} \%=$ Area occupied by wheat or barley.

3. Aggressivity (Agg) according to Mc-Gilchrist (1965).

$$
\mathrm{A}_{\mathrm{ab}} \frac{\mathrm{y}_{\mathrm{ab}}}{\mathrm{y}_{\mathrm{aa}} \times \mathrm{z}_{\mathrm{ab}} \%}-\frac{\mathrm{y}_{\mathrm{ba}}}{\mathrm{y}_{\mathrm{bb}} \times \mathrm{z}_{\mathrm{ba}} \%}
$$

2.1.5. Economic analysis of different intercropping patterns of wheat or barley with sugar cane was carried out according to Nazir et al. (2002).

The proper statistical analysis of the data was done according to Gomez and Gomez (1984). The differences between means of the studied treatments were compared using least significant difference (LSD) at 5\% level.

\subsection{Wheat and Barley}

\section{RESULTS AND DISCUSSION}

The results in Tables $(1 \& 2)$ indicated that intercropping patterns had a significant effect on plant height, grain yield( ardab/ fed) , straw yield(ton/fed)and light transmission\% of wheat and barley, spike length, wt of grains/spike, wt.of 100-grain, No. of grains/spike of barley in the 
two growing seasons, and wt. of 100-grains of wheat in the $1^{\text {st }}$ season. Pure stand of wheat and barley scored the highest values of plant height, No. of grains/spike, grain yield and straw yield. While, intercropping one row of wheat or barley with sugar cane recorded the lowest values of these characters. Intercropping one row of wheat or barley with sugar cane recorded the highest values of light transmission\% among the studied intercropping patterns. Grain yield of wheat or barley was consistently reduced with intercropping patterns. These data are in agreement with those reported by El-Gergawy et al. (1995), Eweida et al. (1996), Zohry (1997), Hussein et al. (2000); Nazir et al. (2002) and Hugar (2006).

Intercropping wheat and sugar cane with three rows resulted the greatest yield reduction\% by $1.61 \%$ and $19.08 \%$ in the $1^{\text {st }}$ season and in the $2^{\text {nd }}$ seasons, respectively. The highest value of light transmission \% was found with intercropping one row of wheat with sugar cane in both seasons. Low availability of light for a component crop in the mixtures reduced the photosynthetic rate and crop growth rate, finally leading to a drastic reduction in grain and straw yields of component crops. Reduction in cane yield as a result of wheat or barley intercropping was attributed to exhaustive competition between the component crops for essential nutrients, water and other growth factors. The aforementioned findings are correlated with those recorded by El-Gergawy et al.(1995) and Eweida et al. (1996).

A diminished significant effect on the sugar yield ton/fed of sugar cane in the case of intercropping wheat with sugar cane was recorded in the $2^{\text {nd }}$ season. The highest values of lack for the sugar yield of sugar cane were with intercropping three rows of wheat, where the reduction rate of sugar yield ton/fed was $21.31 \%$ in the case of intercropping wheat with sugar cane in the $2^{\text {nd }}$ season. It is worth to mention that lowering stalks number and cane yield are due to intra and inter-specific competition between wheat or barley and sugar cane plants especially under the high population density of wheat which consequently affect the sugar cane yield (Tables 3 $\& 4)$. These results are in agreement with those found by Hussein et al. (2000) and Zohry and Abd El. Aal (2003). Intercropping if properly managed and looked after can go a long way to solve the problems of low productivity per unit area and sustainability of a production system. It helps in maintaining the soil fertility and making efficient use of nutrients.

\subsection{Juice quality}

Data in Tables (5\&6) revealed that intercropping patterns of wheat or barley with sugar cane had a significant effect on sugar recovery\% of intercropped sugar cane with wheat and purity $\%$ of intercropped sugar cane with barley in the $1^{\text {st }}$ season. These results might be due to that these traits are the output of the late part of the growing season well after the harvest of wheat or barley. However, sugar yield increased in the sole cane mainly due to the effect of yield rather than its quality. Similar findings were reported by Zohry (1997). He reported that, most sugar cane quality parameters (Brix, sucrose and purity percentages) were unaffected by intercropping. Here too, Nazir et al.(2002) found that sucrose \% of cane juice was not significantly affected by different intercrops (sarsoon, sunflower, wheat, gram, lentil, peas and garlic).

\subsection{Competitive relationships}

Data of competitive relationships and yield advantages for intercropping wheat or barley with sugar cane under three different patterns are presented in Tables $(7 \& 8)$. The results showed that intercropping wheat or barley with sugar cane resulted in an advantage in land equivalent ratio (LER). The value of LER is greater than one; which means increasing the land productivity. The highest values of LER are 1.33 and 1.50 obtained by intercropping three rows of wheat and barley with sugar cane in the $1^{\text {st }}$ and the $2^{\text {nd }}$ seasons, respectively. The lowest values of LER are 1.10 and 1.36 obtained from intercropping two rows of wheat or one row of barley in the $2^{\text {nd }}$ and the $1^{\text {st }}$ seasons, respectively. Relative yield (RY) of sugar cane was the largest at low plant density of wheat or barley, whereas, RY of wheat or barley decreased with increasing the density of wheat or barley plants.

Data of the relative crowding coefficient (RCC) presented in Tables $(7 \& 8)$ show that there was decrease in RCC with increasing plant density of wheat or barley. It could be concluded that the product of the coefficient showed that intercropping sugar cane with wheat or barley increased the land use efficiency. Aggressivity (Agg) values of sugar cane were negative (dominated) while those of wheat or barley were positive (dominant) by intercropping one, two or three rows of wheat and barley with sugar cane in the $1^{\text {st }}$ and the $2^{\text {nd }}$ seasons, except for intercropping three rows of wheat with sugar cane in the $2^{\text {nd }}$ season. This result might be due to that during the winter season; sugar cane grows slowly due to prevailing low temperature, while wheat 
Table (1): Effect of intercropping patterns of wheat with sugar cane on the yield and its components of wheat in 2009/2011 and 2010/2012 seasons.

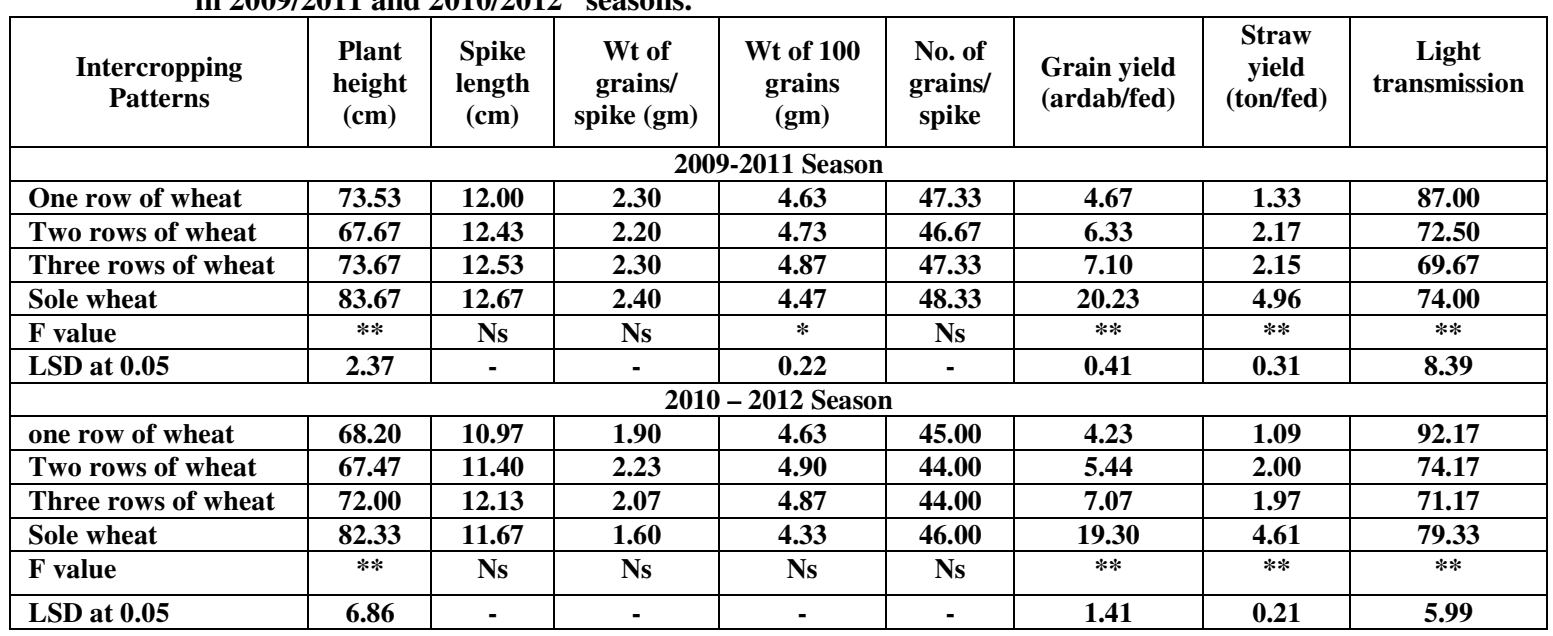

Table (2): Effect of intercropping patterns of barley with sugar cane on the yield and its components of barley in 2009/2011 and 2010/2012 seasons.

\begin{tabular}{|c|c|c|c|c|c|c|c|c|}
\hline Intercropping patterns & $\begin{array}{c}\text { Plant } \\
\text { height } \\
(\mathbf{c m})\end{array}$ & $\begin{array}{c}\text { Spike } \\
\text { length } \\
\text { (cm) }\end{array}$ & $\begin{array}{c}\text { Wt of } \\
\text { grains/ } \\
\text { spike }(\mathrm{gm})\end{array}$ & $\begin{array}{c}\text { Wt of } 100 \\
\text { grains } \\
\text { (gm) }\end{array}$ & $\begin{array}{l}\text { No.of } \\
\text { grains/ } \\
\text { spike }\end{array}$ & $\begin{array}{l}\text { Grain yield } \\
\text { (ardab/fed) }\end{array}$ & $\begin{array}{c}\text { Straw } \\
\text { yield } \\
\text { (ton/fed) }\end{array}$ & $\begin{array}{c}\text { Light } \\
\text { transmission }\end{array}$ \\
\hline \multicolumn{9}{|c|}{ 2009-2011 Season } \\
\hline One row of barley & 60.20 & 7.60 & 2.03 & 4.33 & 52.00 & 6.73 & 2.01 & 77.83 \\
\hline Two rows of barley & 63.07 & 7.63 & 2.17 & 4.47 & 48.00 & 7.63 & 2.27 & 68.67 \\
\hline Three rows of barley & 68.37 & 8.03 & 2.10 & 4.57 & 46.33 & 8.80 & 2.80 & 66.17 \\
\hline Sole barley & 82.00 & 8.30 & 3.00 & 4.37 & 46.00 & 17.73 & 6.00 & 70.67 \\
\hline F value & $* *$ & $* *$ & $* *$ & $*$ & $*$ & $* *$ & $* *$ & $* *$ \\
\hline LSD0.05 & $\mathbf{1 . 5 3}$ & 0.30 & 0.37 & 0.12 & 3.41 & 0.31 & 0.36 & 5.36 \\
\hline \multicolumn{9}{|c|}{$2010-2012$ Season } \\
\hline One row of barley & 58.80 & 7.20 & 1.93 & 4.50 & 43.70 & 4.13 & $\mathbf{1 . 5 5}$ & 84.83 \\
\hline Two rows of barley & 61.00 & 7.80 & 1.80 & 4.30 & 40.33 & 5.10 & 1.24 & 70.50 \\
\hline Three rows of barley & 62.70 & 8.20 & 1.60 & 4.20 & 40.33 & 5.95 & 2.09 & 70.83 \\
\hline Sole barley & 82.00 & 8.10 & 2.93 & 3.90 & 47.00 & 12.17 & 4.03 & 74.83 \\
\hline F value & $* *$ & $* *$ & $* *$ & $*$ & $*$ & $* *$ & $* *$ & $* *$ \\
\hline LSD0.05 & 6.30 & 0.38 & 0.65 & 0.25 & 1.29 & 0.89 & 0.61 & 2.18 \\
\hline
\end{tabular}

Table (3): Effect of intercropping patterns of wheat with sugar cane on the yield and its components of sugar cane in 2009/2011 and 2010/2012 seasons.

\begin{tabular}{|c|c|c|c|c|c|c|c|}
\hline $\begin{array}{l}\text { Intercropping } \\
\text { patterns }\end{array}$ & $\begin{array}{c}\text { Stalk } \\
\text { height } \\
(\mathrm{cm})\end{array}$ & $\begin{array}{c}\text { Stalk } \\
\text { diameter } \\
(\mathrm{cm})\end{array}$ & $\begin{array}{c}\text { Stalk } \\
\text { weight } \\
\text { (kg) }\end{array}$ & $\begin{array}{c}\text { No. of } \\
\text { stalks/ m² }\end{array}$ & $\begin{array}{c}\text { Cane } \\
\text { yield } \\
\text { (ton/fed) }\end{array}$ & $\begin{array}{c}\text { Sugar } \\
\text { yield } \\
\text { (ton/fed) }\end{array}$ & $\begin{array}{c}\text { Light } \\
\text { transmission }\end{array}$ \\
\hline \multicolumn{8}{|c|}{ 2009-2011 Season } \\
\hline One row of wheat & 290.00 & 2.10 & 1.73 & 9.50 & 52.28 & 5.80 & 91.83 \\
\hline Two rows of wheat & 288.70 & 2.50 & 1.57 & 7.60 & 51.91 & 5.60 & 82.50 \\
\hline Three rows of wheat & 290.70 & 2.30 & 1.77 & 7.30 & 51.47 & 5.20 & 88.00 \\
\hline Sole sugar cane & 288.30 & 2.20 & 1.53 & 7.50 & 52.31 & 5.80 & 86.83 \\
\hline F value & Ns & $*$ & Ns & Ns & $* *$ & Ns & $* *$ \\
\hline LSD at 0.05 & - & 0.35 & - & - & 0.77 & - & 1.42 \\
\hline \multicolumn{8}{|c|}{ 2010-2012 Season } \\
\hline One row of wheat & 224.00 & 2.70 & 1.33 & 9.70 & 50.20 & 6.20 & 92.17 \\
\hline Two rows of wheat & 217.00 & 2.60 & 1.21 & 9.80 & 41.43 & 5.10 & 83.50 \\
\hline Three rows of wheat & 215.00 & 2.50 & 1.31 & 7.80 & 40.70 & 4.80 & 87.67 \\
\hline Sole sugar cane & 223.00 & 2.70 & 1.40 & 8.60 & 50.30 & 6.10 & 87.17 \\
\hline F value & $* *$ & Ns & Ns & Ns & $* *$ & $* *$ & $* *$ \\
\hline LSD at 0.05 & 3.07 & - & - & - & 0.63 & 1.94 & 1.12 \\
\hline
\end{tabular}


Table (4): Effect of intercropping patterns of barley with sugar cane on the yield and its components of sugar cane in 2009/2011 and 2010/2012 seasons.

\begin{tabular}{|c|c|c|c|c|c|c|c|}
\hline $\begin{array}{l}\text { Intercropping } \\
\text { patterns }\end{array}$ & $\begin{array}{c}\text { Stalk } \\
\text { height } \\
(\mathrm{cm})\end{array}$ & $\begin{array}{c}\text { Stalk } \\
\text { diameter } \\
(\mathrm{cm})\end{array}$ & $\begin{array}{c}\text { Stalk } \\
\text { weight } \\
(\mathrm{kg})\end{array}$ & $\begin{array}{c}\text { No. of } \\
\text { stalks/ } \\
\text { m }^{2}\end{array}$ & $\begin{array}{c}\text { Cane } \\
\text { yield } \\
\text { (ton/fed) }\end{array}$ & $\begin{array}{c}\text { Sugar } \\
\text { yield } \\
\text { (ton/fed) }\end{array}$ & $\begin{array}{c}\text { Light } \\
\text { transmission }\end{array}$ \\
\hline \multicolumn{8}{|c|}{ 2009-2011 Season } \\
\hline One row of barley & 272.30 & 2.33 & 1.50 & 8.10 & 52.40 & 6.13 & 86.00 \\
\hline Two rows of barley & 267.30 & 2.70 & 1.60 & 7.90 & 51.70 & 5.70 & 86.00 \\
\hline $\begin{array}{lll}\begin{array}{l}\text { Three } \\
\text { barley }\end{array} & \text { rows of } \\
\end{array}$ & 265.30 & 2.50 & 1.50 & 7.80 & 50.60 & 5.60 & 87.67 \\
\hline Sole sugar cane & 276.70 & 2.50 & 1.50 & 8.50 & 53.30 & 6.50 & 87.89 \\
\hline F value & $* *$ & $* *$ & Ns & Ns & Ns & Ns & $* *$ \\
\hline LSD at 0.05 & 5.32 & 0.13 & - & - & - & - & 0.93 \\
\hline \multicolumn{8}{|c|}{ 2010-2012 Season } \\
\hline One row of barley & 215.70 & 2.50 & 1.37 & 8.60 & 49.70 & 6.30 & 85.67 \\
\hline Two rows of barley & 210.70 & 2.80 & 1.37 & 8.50 & 48.60 & 5.90 & 85.17 \\
\hline $\begin{array}{l}\text { Three rows of } \\
\text { barley }\end{array}$ & 213.70 & 2.90 & 1.43 & 7.80 & 46.80 & 5.80 & 86.67 \\
\hline Sole sugar cane & 220.30 & 2.60 & 1.40 & 8.80 & 50.70 & 6.23 & 87.33 \\
\hline F value & $* *$ & $* *$ & Ns & $* *$ & Ns & Ns & Ns \\
\hline LSD at 0.05 & 3.42 & 1.67 & - & 0.39 & - & - & - \\
\hline
\end{tabular}

Table (5): Effect of intercropping patterns of wheat with sugar cane on the quality parameters of sugar cane in 2009/2011 and 2010/2012 seasons.

\begin{tabular}{|c|c|c|c|c|c|c|}
\hline $\begin{array}{c}\text { Intercropping } \\
\text { patterns }\end{array}$ & $\begin{array}{c}\text { TSS } \\
\%\end{array}$ & $\begin{array}{c}\text { Sucrose } \\
\%\end{array}$ & $\begin{array}{c}\text { Purity } \\
\%\end{array}$ & $\begin{array}{c}\text { Pol } \\
\%\end{array}$ & $\begin{array}{l}\text { Reducing } \\
\text { sugars \% }\end{array}$ & $\begin{array}{c}\text { Sugar } \\
\text { recovery\% }\end{array}$ \\
\hline \multicolumn{7}{|c|}{ 2009-2011 Season } \\
\hline One row of wheat & 20.33 & 16.90 & 83.13 & 13.83 & 0.41 & 11.28 \\
\hline Two rows of wheat & 20.00 & 16.43 & 82.10 & 13.53 & 0.41 & 10.90 \\
\hline Three rows of wheat & 20.00 & 16.40 & 81.70 & 13.51 & 0.46 & 10.50 \\
\hline Sole sugar cane & 19.37 & 16.40 & 83.40 & 13.40 & 0.37 & 11.60 \\
\hline F value & Ns & Ns & Ns & Ns & Ns & $*$ \\
\hline LSD at 0.05 & - & - & - & - & - & 0.96 \\
\hline \multicolumn{7}{|c|}{ 2010-2012 Season } \\
\hline One row of wheat & 21.70 & 18.50 & 85.30 & 14.90 & 0.30 & 12.50 \\
\hline Two rows of wheat & 21.30 & 18.20 & 85.20 & 14.70 & 0.30 & 12.20 \\
\hline Three rows of wheat & 20.80 & 17.60 & 84.40 & 14.30 & 0.40 & 11.80 \\
\hline Sole sugar cane & 21.00 & 17.90 & 85.30 & 14.40 & $\mathbf{0 . 3 3}$ & 12.10 \\
\hline F value & Ns & Ns & Ns & Ns & Ns & Ns \\
\hline LSD at 0.05 & - & - & - & - & - & - \\
\hline
\end{tabular}

Table (6): Effect of intercropping patterns of barley with sugar cane on the quality parameters of sugar cane in 2009/2011 and 2010/2012 seasons.

\begin{tabular}{|c|c|c|c|c|c|c|}
\hline $\begin{array}{c}\text { Intercropping } \\
\text { patterns }\end{array}$ & $\begin{array}{c}\text { TSS } \\
\%\end{array}$ & $\begin{array}{c}\text { Sucrose } \\
\%\end{array}$ & $\begin{array}{c}\text { Purity } \\
\%\end{array}$ & $\begin{array}{c}\text { Pol } \\
\%\end{array}$ & $\begin{array}{l}\text { Reducing } \\
\text { sugars \% }\end{array}$ & $\begin{array}{c}\text { Sugar } \\
\text { recovery \% }\end{array}$ \\
\hline & \multicolumn{6}{|c|}{ 2009-2011 Season } \\
\hline One row of barley & 21.00 & 17.70 & 84.10 & $\mathbf{1 4 . 3 3}$ & 0.47 & 11.70 \\
\hline Two rows of barley & 20.20 & 16.40 & 81.30 & 13.63 & 0.43 & 10.90 \\
\hline Three rows of barley & 19.80 & 16.60 & 83.40 & $\mathbf{1 2 . 6 5}$ & $\mathbf{0 . 3 3}$ & 11.04 \\
\hline Sole sugar cane & 21.50 & 18.00 & 83.60 & 14.68 & 0.40 & 12.10 \\
\hline F value & Ns & Ns & $* *$ & Ns & Ns & Ns \\
\hline LSD at 0.05 & - & - & 4.54 & - & - & - \\
\hline \multicolumn{7}{|c|}{ 2010-2012 Season } \\
\hline One row of barley & 21.20 & 18.80 & 84.70 & 15.20 & 0.27 & 12.70 \\
\hline Two rows of barley & 21.30 & 18.10 & 84.80 & 14.60 & 0.27 & 12.20 \\
\hline Three rows of barley & 21.50 & 18.30 & 85.30 & 14.80 & 0.27 & 12.40 \\
\hline Sole sugar cane & 21.50 & 18.30 & 85.30 & 14.80 & 0.30 & 12.40 \\
\hline F value & Ns & Ns & Ns & Ns & Ns & Ns \\
\hline LSD at 0.05 & - & - & - & - & - & - \\
\hline
\end{tabular}


Table (7): Calculated data of competitive relationships and yield advantage for cropping patterns of wheat with sugar cane in 2009/2011 and 2010/2012 seasons.

\begin{tabular}{|c|c|c|c|c|}
\hline $\begin{array}{c}\text { Intercropping } \\
\text { patterns }\end{array}$ & $\begin{array}{l}\text { Land equivalent } \\
\text { ratio (LER) } \\
\text { Lc }+\mathbf{L}_{W}=\mathbf{L E R}\end{array}$ & $\begin{array}{l}\text { Relative crowding } \\
\text { coefficient (RCC) } \\
\mathbf{K}_{\mathbf{C}} * \quad \mathbf{K}_{\mathbf{W}}=\mathbf{K}\end{array}$ & \multicolumn{2}{|c|}{ Aggressivity (Agg) } \\
\hline \multicolumn{5}{|c|}{ 2009-2011 Season } \\
\hline One row of wheat & $1.0+0.23=1.23$ & $260 * 2.01=522.6$ & -0.63 & +.63 \\
\hline Two rows of wheat & $0.99+0.31=1.30$ & $36.60 * 1.60=58.93$ & -0.07 & +0.07 \\
\hline Three rows of wheat & $0.98+0.35=1.33$ & $27.54 * 1.20=33.16$ & $+\mathbf{0 . 3 0}$ & -0.30 \\
\hline \multicolumn{5}{|c|}{ 2010-2012 Season } \\
\hline One row of wheat & $0.99+0.22=1.21$ & $57.06 * 1.88=141.12$ & -0.53 & +0.53 \\
\hline Two rows of wheat & $0.82+0.28=1.10$ & $1.40 * 1.31=1.83$ & -0.16 & +0.16 \\
\hline Three rows of wheat & $0.81+0.37=1.18$ & $1.91 * 1.29=2.46$ & -0.01 & $+\mathbf{+ 0 . 0 1}$ \\
\hline \multicolumn{2}{|l|}{$\begin{array}{l}\text { Lc: LER Sugar cane } \\
\mathrm{L}_{\mathrm{W}}: \text { LER wheat }\end{array}$} & $\begin{array}{l}K_{C}: \text { RCC Sugar cane } \\
K_{W}: \text { RCC wheat }\end{array}$ & \multicolumn{2}{|c|}{$\begin{array}{l}A_{C}: \text { Agg Sugar cane } \\
A_{W}: \text { Agg wheat }\end{array}$} \\
\hline
\end{tabular}

Table (8): Calculated data of competitive relationships and yield advantage for cropping patterns of barley with sugar cane in 2009/2011 and 2010/2012 seasons.

\begin{tabular}{|c|c|c|c|c|}
\hline $\begin{array}{l}\text { Intercropping } \\
\text { patterns }\end{array}$ & $\begin{array}{l}\text { Land equivalent } \\
\text { ratio (LER) } \\
\mathbf{L c}+\mathbf{L}_{W}=\mathbf{L E R}\end{array}$ & $\begin{array}{l}\text { Relative crowding } \\
\text { coefficient (RCC) } \\
\mathbf{K}_{\mathbf{C}} * \mathbf{K}_{\mathbf{W}}=\mathbf{K}\end{array}$ & $\begin{array}{l}\text { Aggre } \\
\mathbf{A}_{\mathrm{C}}\end{array}$ & (Agg) \\
\hline \multicolumn{5}{|l|}{ 2009-2011 Season } \\
\hline One row of barley & $0.98+0.38=1.36$ & $8.73 * 4.10=35.79$ & -1.80 & +1.80 \\
\hline Two rows of barley & $0.97+0.43=1.40$ & $9.67 * 2.53=24.47$ & -0.61 & +0.61 \\
\hline Three rows of barley & $0.95+0.50=1.45$ & $8.44 * 2.19=18.48$ & -0.22 & +0.22 \\
\hline \multicolumn{5}{|l|}{ 2010-2012 Season } \\
\hline One row of barley & $0.98+0.39=1.37$ & $7.43 * 4.24=31.50$ & -1.84 & +1.84 \\
\hline Two rows of barley & $0.96+0.51=1.47$ & $6.90 * 3.43=23.67$ & -0.93 & +0.93 \\
\hline Three rows of barley & $0.92+0.58=1.50$ & $5.39 * 3.03=16.33$ & -0.50 & +0.50 \\
\hline 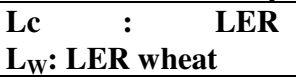 & Sugar cane & $\begin{array}{l}K_{C}: R C C \text { Sugar cane } \\
K_{W}: \text { RCC wheat }\end{array}$ & $\begin{array}{l}\mathbf{A}_{\mathbf{C}}: \\
\mathbf{A}_{\mathrm{W}}:\end{array}$ & $\begin{array}{l}\text { hugar cane } \\
\text { heat }\end{array}$ \\
\hline
\end{tabular}

and barley grow strongly. These results of competition relationship and yield advantage are in agreement with those obtained by El- Gergawi et al. (1995) and Zohry et al. (2003).

\subsection{Economical evaluation and net profit}

It is evident from Tables $(9 \& 10)$ that intercropping one, two or three rows of wheat and barley with sugar cane led to increase the total income and net profit LE/fed compared with pure stand of sugar cane, wheat or barley. The results indicated that intercropping one, two or three rows of wheat with sugar cane led to increasing net profit LE/fed by 32.36 , in the $1^{\text {st }}$ season and 29.40 , 8.77 and $8.65 \%$ in the $2^{\text {nd }}$ season, respectively. However, intercropping one, two or three rows of barley with sugar cane led to increasing net profit LE/fed by $44.53,45.52$ and $49.55 \%$ in the $1^{s t}$ season and $31.48,23.21$ and $28.10 \%$ in the $2^{\text {nd }}$ season, respectively. Intercropping sugar cane planted with wheat or barley gave the highest net profit compared with sole cropped treatments.

It could be concluded that the higher values of net profit LE/fed were scored from intercropping barley with sugar cane than intercropping wheat with sugar cane. This means that intercropping barley with sugar cane achieved net profit LE/fed better than intercropping wheat with sugar cane. Also, intercropping two rows of wheat with sugar cane in the $1^{\text {st }}$ season and one row of wheat with sugar cane in the $2^{\text {nd }}$ season, achieved the highest value of net profit LE/fed. On the other hand, intercropping three rows of barley with sugar cane in the $1^{\text {st }}$ season and one row of Wheat with sugar cane in the $2^{\text {nd }}$ season, achieved the highest value of net profit LE/fed. These results are in a good agreement with those found by Zohry (1997) and Farghaly (2003).

Finally, it could be recommended to intercropping one or two rows of wheat with sugar cane if sugar cane was harvested early, but if for any reason, cutting of sugar cane delayed, in this case, the intercropping of barley with sugar cane is appropriate and best under Middle Egypt conditions. 
Table (9): Economic analysis of different intercropping patterns of wheat with sugar cane in 2009/2011and 2010/2012 seasons.

\begin{tabular}{|c|c|c|c|c|c|c|c|c|c|}
\hline \multirow[b]{2}{*}{$\begin{array}{l}\text { Intercropping } \\
\text { patterns }\end{array}$} & \multicolumn{3}{|c|}{$\begin{array}{l}\text { Crop yield } \\
\end{array}$} & \multicolumn{3}{|c|}{ Income (LE/fed) } & \multirow{2}{*}{$\begin{array}{l}\text { Total } \\
\text { income } \\
(\text { LE/fed) }\end{array}$} & \multirow{2}{*}{$\begin{array}{l}\text { Total } \\
\text { expenditure } \\
\text { (LE/fed) }\end{array}$} & \multirow{2}{*}{$\begin{array}{l}\text { Total } \\
\text { profit } \\
\text { (LE/fed) }\end{array}$} \\
\hline & $\begin{array}{l}\text { Sugar cane } \\
\text { ton/fed }\end{array}$ & $\begin{array}{l}\text { Wheatar } \\
\text { dab/ } \\
\text { fed }\end{array}$ & $\begin{array}{l}\text { Straw } \\
\text { ton/ } \\
\text { fed }\end{array}$ & $\begin{array}{l}\text { Sugar } \\
\text { cane }\end{array}$ & Wheat & Straw & & & \\
\hline \multicolumn{10}{|c|}{ 2009-2011 Season } \\
\hline $\begin{array}{l}\text { One row of } \\
\text { wheat }\end{array}$ & 52.28 & 4.67 & 1.33 & 17513.8 & 1634.5 & 1596 & 20744.3 & $\mathbf{8 8 0 0}$ & 11944.3 \\
\hline $\begin{array}{l}\text { Two rows of } \\
\text { wheat }\end{array}$ & 51.91 & 6.33 & 2.17 & 17389.9 & 2215.5 & 2604 & 22209.4 & 9100 & 13109.4 \\
\hline $\begin{array}{l}\text { Three rows of } \\
\text { wheat }\end{array}$ & 51.47 & 7.10 & 2.15 & $\mathbf{1 7 2 4 2 . 5}$ & 2485 & 2580 & 22307.5 & 9400 & 12907.5 \\
\hline Sole wheat & - & 20.23 & 4.96 & - & 7080.5 & 5952 & 13032.5 & 6500 & 6532.5 \\
\hline Sole sugar cane & 52.31 & - & - & 17523.9 & - & - & $\mathbf{1 7 5 2 3 . 9}$ & 8500 & 9023.9 \\
\hline \multicolumn{10}{|c|}{ 2010-2012 Season } \\
\hline $\begin{array}{l}\text { One row of } \\
\text { wheat }\end{array}$ & 50.20 & 4.23 & 1.09 & 16817 & 1480.5 & 1308 & 19605.5 & 8800 & 10805.5 \\
\hline $\begin{array}{l}\text { Two rows of } \\
\text { wheat }\end{array}$ & 41.43 & 5.44 & 2.00 & 13879.05 & 1904 & 2400 & 18183.1 & 9100 & 9083.1 \\
\hline $\begin{array}{l}\text { Three rows of } \\
\text { wheat }\end{array}$ & 40.70 & 7.07 & 1.97 & 13634.5 & 2474.5 & 2364 & 18473 & 9400 & 9073 \\
\hline Sole wheat & - & 19.30 & 4.61 & - & 6755 & 5532 & 12287 & 6500 & 5787 \\
\hline Sole sugar cane & 50.30 & - & - & 16850.5 & - & - & 16850.5 & 8500 & 8350.5 \\
\hline
\end{tabular}

Table (10): Economic analysis of different intercropping patterns of barleuy with sugar cane in 2009/2011 and 2010/2012 seasons.

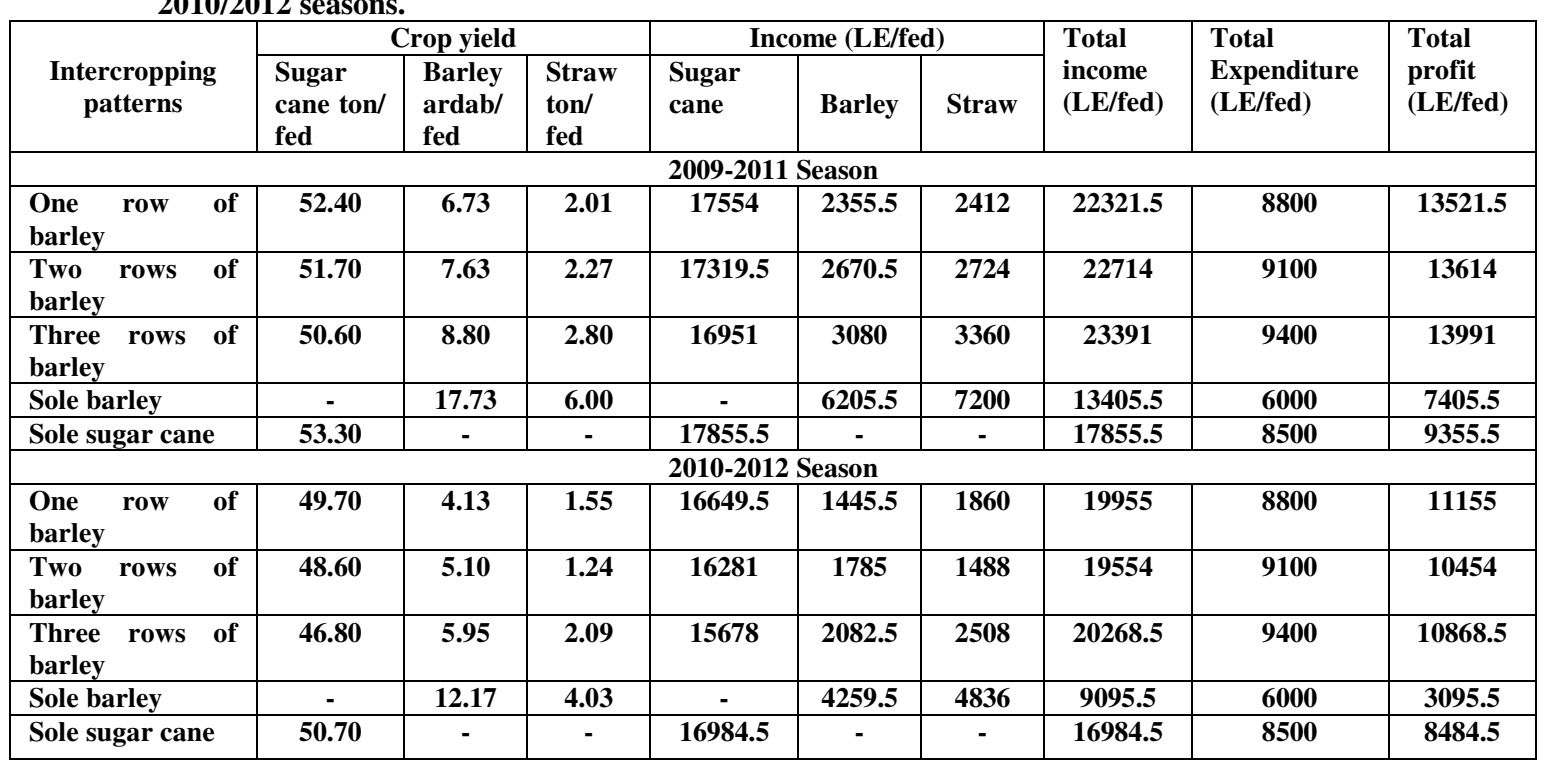

\section{REFERENCES}

A.O.A.C. (2005). Association of Official Analytical Chemists. Official methods of analysis, $16^{\text {th }}$ Ed. AOAC International, Washington, D.C., USA.

CCSC (2012). Central Council for Sugar Crops. Annual Report, Ministry of Agriculture, Egypt.

El-Gergawi A.S., Saif, Laila M., Taha, Nour El.Hoda M. and El. Geddawy E.H. (1995). The relative benefit of intercropping maize with spring cane in middle Egypt. J.Appl. Sci.10(2):525-632.

Eweida M.H.T., Osman M.S.A., Shams S.A.A. and Zohry A.H.A. (1996). Effect of some intercropping of soybean with sugar cane on growth, yield and quality of both components. Annuls of Agric. Sci. Moshtohor, 34(2):473486.

Farghaly B.S.(2003). Evaluation of intercropping sugar beet and sugar cane and its effect on growth, yield and juice quality.J. Agric. Sci.Mansoura Univ. ,28(3): 1567-1577.

Gomez K.A. and Gomez A.A (1984). Statistical procedures for agriculture research. A Wiley-Inter Science Publication, John Wiley and sons, Inc. New York, USA.

Hall R.L. (1974). Analysis of nature of interference between plants of different species,Aust., J. Res. 35:749-756

Hugar H. Y. ( 2006 ). Studies on maize based 
vegetable intercropping systems in vertisols of Northern Zone of Karnataka .M.Sc. College of Agric., Dharwad, Univer. Agric. Sci. Dharwad.

Hussein S.Z., Sheraz F., Sherin K., Farid S. and Khans S. (2000). Effect of intercropping on ratoonability of sugar cane under NP fertilization. Sarhad J. of Agric.,16(4): 435439.

Jackson M.L. (1967). Soil chemical analysis. Prentice-Hall, Inc, Englewood Cliffs, NJ, USA.

Mathur R. B. (1981). Handbook of cane sugar technology. Oxford \& IBH Publishing Co.

Mc-Gilchrist C.A.(1965). Analysis of competition on experiments biometrics .21: 975-985.

Mendoza T.C. (1986). Light interception and total biomass productivity in sugar cane intercropping. Philipp J. Crop Sci.11(3):181187.
Nazir M.S , Ahmad A.J. I. , Nawaz S. and Bhatti I.H. (2002). Production potential and economics of intercropping in Autumn-planted sugar cane. International J. Agric. \& Biology, 4(1): 140-142.

Satisha G.C., Krishnappa M. and Srikanth K. (1996). Input of sulphur on yield and quality of sugar cane. Indian Sugar J. 45(9): 397-401.

Willey R.W. (1979). Inter cropping, its importance and research needs . part 1competitions and yield advantages. Field Crop Abst.32:1-10.

Zohry A.H.A.(1997). Effect of intercropping onion with autumn sugar cane on cane yield and juice quality. J.Agric, Res., 77(1): 173187.

Zohry A.H.A. and Abd El.Aal A.I.N. (2003). Soil morphological features and competition of intercropping mung bean with sugar cane in Upper Egypt . Egypt. J.Agric.Res., 81(1): 1-14.

\section{إنتاجية وجودة خلقة قصب السكر الخريفى المحملة بالقمح أوالثعير تحت ظروف مصر الوسطى \\ نجوى رفعت احمد -خليل الشناوى محمد* - حسين فرويز \\ معهد بحوث المحاصيل الحقلية * معهد بحوث المحاصيل السكرية - مركز البحوث الزر اعية - الجيزة - مصر}

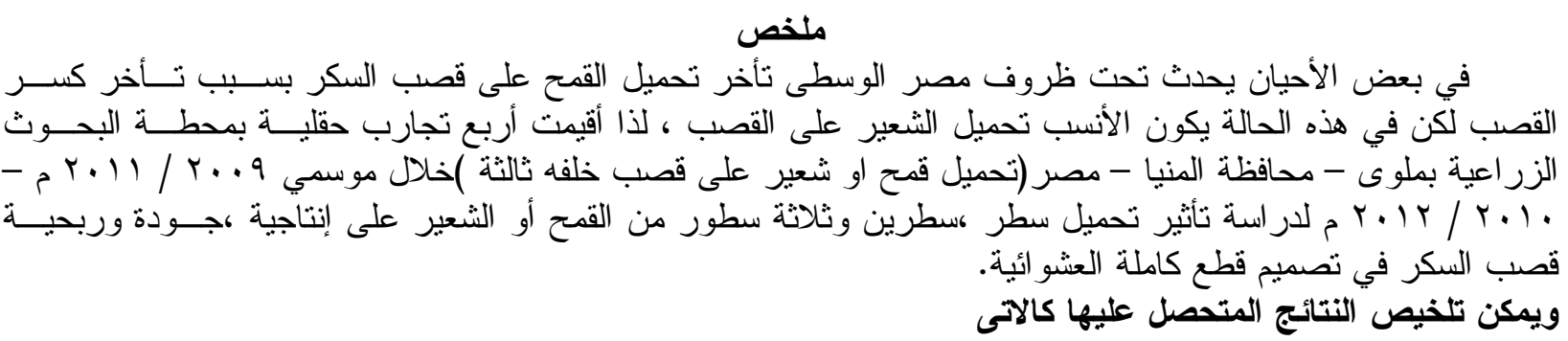

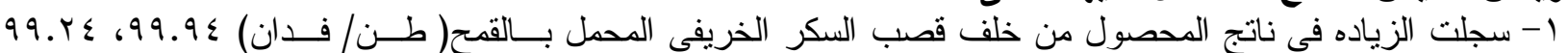

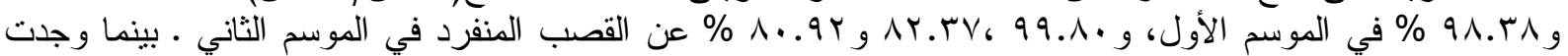

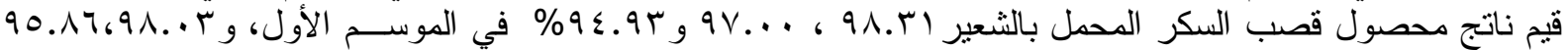

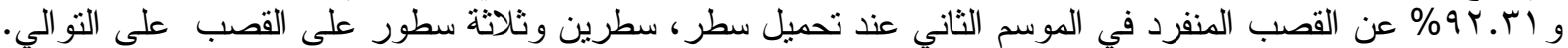

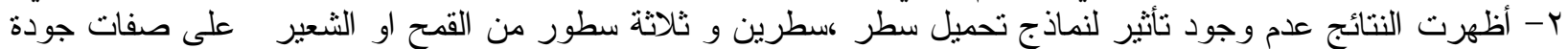

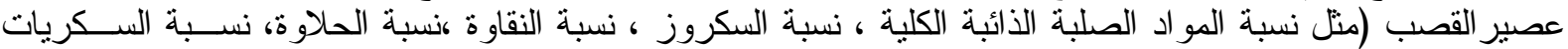
المختزلة ونسبة استخر اج السكر ) عدا نسبة استخر اج السكر في الموسم الاول للقصب المحمل بالقمح و نسبة النقاوة في

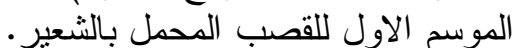

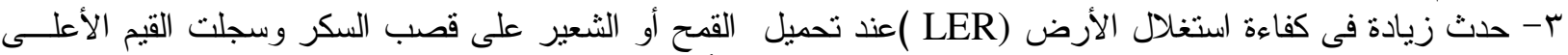

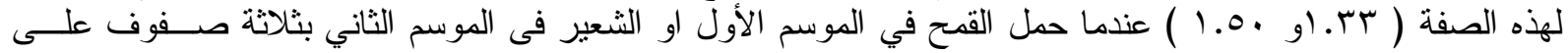
القصب على التو الي. التمان.

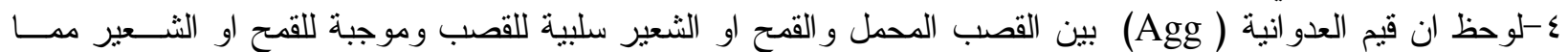

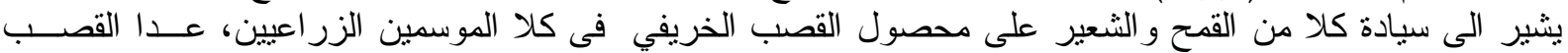

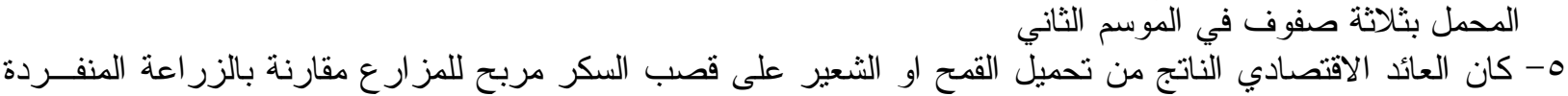

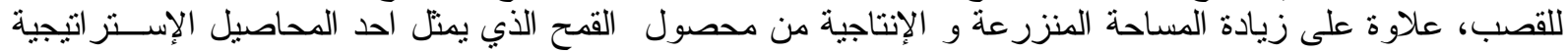




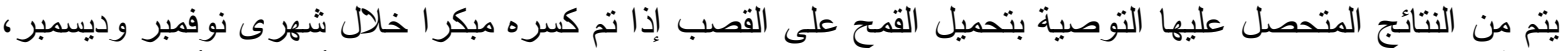

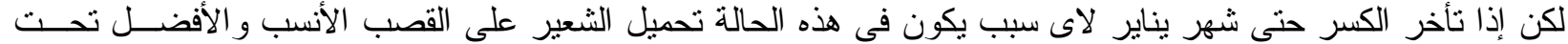

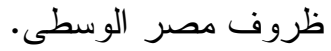

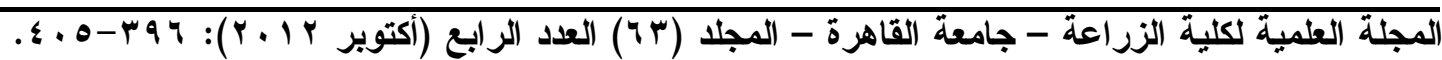

